Copy 1

The Oxygen I

1412

110 Shellfiah.

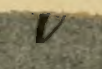

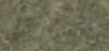




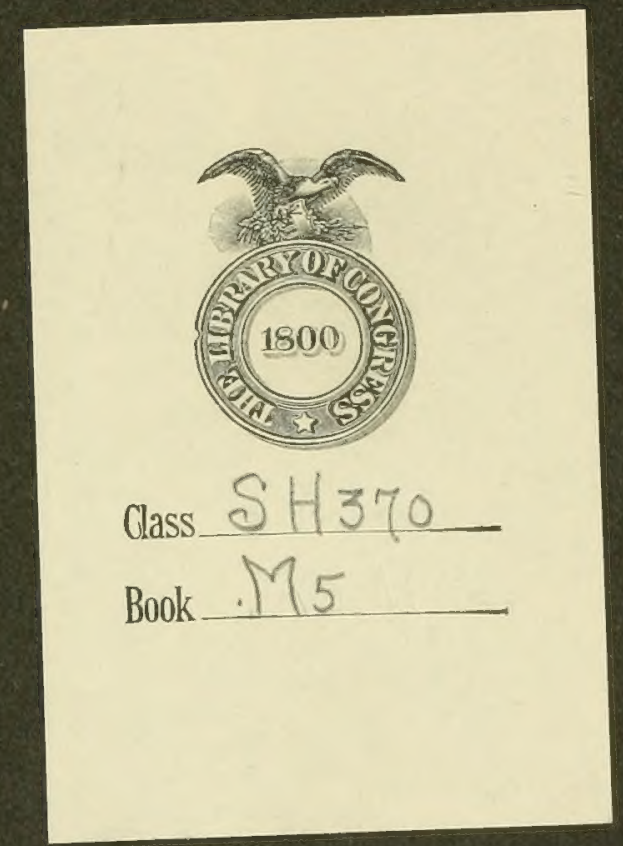


FROM BULLETIN OF THE UNITED STATES BUREAU OF FISHERIES : VOLUME XXXII, 1912

Document $787 \quad: \quad: \quad: \quad: \quad: \quad: \quad: \quad: \quad:$ Issued February 18, 1914.

THE OXYGEN REQUIREMENTS OF SHELLFISH

$*$

By Philip H. Mitchell

$16284^{\circ}-14$ 
SH370

.$M 5$

Di OF D.

MA 41914 


\title{
THE OXYGEN REQUIREMENTS OF SHELLFISH.
}

\author{
By PHIL,IP H. MITCHELL.
}

The respiratory exchanges in lamellibranchs seem not to have been investigated. Probably the most notable work related to it is that of Vernon. ${ }^{a}$ He measured the oxygen utilization and carbon dioxide emission in a large number of marine forms, including certain Mollusca but no lamellibranchs. He showed that in the lower marine forms investigated, including Coelenterata, Tunicata, and Mollusca, the respiratory exchange was very small compared to the higher ones, for example, teleosts. There were, however, certain exceptions to this rule, notably the protozoan Collozoum inerme, which showed nearly as high a respiratory exchange as the fishes. He found also that, in general, the respiratory activity was more readily responsive to temperature in the lower than in the higher forms. He further showed that the gaseous exchange was relatively greater in the small than in the large individuals of the same species and found that, in general, the same distinction held between small and large species. "The transparent pelagic animals were shown to have a very small proportion of solid organic matter in their tissues, so that calculated on that basis their respiratory activity was very large, greater indeed than fishes, amphibians, or even mammals.

In the present work some of those findings have been confirmed for the lamellibranchs. They show a ready responsiveness to temperature changes, a smaller utilization of oxygen in proportion to the body weight with increase in size, and those forms which showed a low oxygen requirement in relation to their entire weight showed a higher utilization in proportion to their dried weight.

The resistance to lack of oxygen in forms which have no power of locomotion is an important factor in adverse conditions. This is especially true of the edible shellfish, which, because of enforced closure during cold weather, or in the presence of polluted or roily water, or in water whose oxygen has been lowered by the presence of certain wastes or an abundance of life, must at times be deprived of their normal supply of oxygen. The subject therefore possesses an economic significance, and it was, in fact, the possibility that certain manufacturing wastes, removing oxygen from sea water, might therefore cause the death of oysters and clams which first directed the writer's attention to the subject. The particular wastes involved were those of gas works con- 
taining at least traces and sometimes significant quantities of water-gas tar and other oily matter. The results of this investigation indicate, in a word, that the tar or oily wastes could have no effect on shellfish in this way. The details of this part of the work, however, are reserved for a report dealing specifically with the effect of water-gas tar on oysters. This paper is confined to oxygen requirements of shellfish and their resistance to lack of oxygen.

\section{METHOD OF EXPERIMENT.}

The method of manipulation was, in brief, to place the shellfish in a desiccator completely filled with sea water of known content of dissolved oxygen, leave the apparatus at some constant temperature during a definite period, and then to sample the water in the desiccator so as to compute its decrease in dissolved oxygen. Winkler's wellknown titration method was used to measure the oxygen both at the beginning and end of each experiment. A vacuum desiccator was used for the containing vessel because it could easily be closed water-tight, could accommodate almost any size of shellfish, and enabled one to take through the side opening with glass stopcock a fair sample of the contents.

In practice a number of precautions were found necessary. The hollow dome of the desiccator cover was entirely filled with paraffin to exclude air from entrapment in it. A glass tube within the desiccator was connected to its side stopcock and reached nearly to the bottom. When, therefore, the filled desiccator was opened at the top water could be sucked off through the opened side cock into the sampling bottle so that the sample would come from a point well below the surface of the water, where the oxygen content would be fairly constant. The sea water ${ }^{a}$ used in each experiment was brought to the required temperature and placed in a large reservoir jar on a shelf, from which it could be siphoned without bubbling into the desiccator. When it was thus nearly filled, an oyster was gently placed on a glass tripod, where it would rest near the center of the desiccator. With clams it was found necessary to leave them in the desiccator submerged in water for a few hours before the experiment, because, unlike oysters, they would not open quickly after they had been handled. In either case, though, water from the shelf reservoir was siphoned into the overflowing desiccator for sufficient time to bring the oxygen content to approximate constancy and then the cover was put on, leaving just opening enough to admit the siphon tube.

The side cock of the desiccator was then connected by rubber tubing to the sampling bottle, and after starting by suction the water was allowed to siphon through the bottle two to three minutes. This period was found quite sufficient to give reliable duplicate results for water containing any percentage of oxygen measured in these experiments. The water running into the desiccator meantime was in excess of that running into the bottle, so that an overflow was maintained from the top of the desiccator and the sample rendered as fair as possible. At the exact second recorded as the beginning of the experiment the side stopcock was closed, the siphon quickly withdrawn from the desiccator, 
and its lid put completely on, excluding bubbles. The entire apparatus was then kept in a bath of sea water whose temperature was maintained approximately the same as the water within the desiccator. The oxygen in the sample was meantime measured by titration.

After a period, usually about an hour in length, the desiccator was two or three times inverted to render its contents uniform and to stimulate the shellfish to close and thus stop using oxygen. The exact time of the first rough movement of the apparatus was recorded as the closing time of the experiment. The outside of the desiccator was then dried with a towel and the entire apparatus weighed. When currents in the water had come practically to rest, the side stopcock was again connected to the same sampling bottle used at the beginning of the experiment and a sample taken as before. Since the capacity of the desiccators was sufficient for 1,200 grams of water, even with the large shellfish, and as the sampling bottles held approximately 300 grams, it is plain that water could run through the sampling bottle some time without emptying the desiccator. The stream indeed was allowed to run at least two minutes. The capacity of the desiccators was not enough to permit of taking a duplicate sample that would be reliable, but this was not necessary because there is little chance of error in the Winkler's titration.

The last step in the process was to empty the desiccator completely, dry it and the shellfish, and weigh them together. This gave a means of determining by difference the weight of the water. It was probably accurate to within 2 grams. As the dissolved oxygen of the water both at the beginning and the end of the experiment was calculated in parts per million, it was only necessary to multiply the weight of water used by the decrease in its oxygen content expressed in parts per million and divide the result by 100 to find the decimilligrams of oxygen used by the shellfish. Experiment showed that no correction for change in the oxygen content of the water due to microorganisms or physical factors was, under the circumstances of constant temperature, etc., necessary. Results were expressed in decimilligrams of oxygen per hour and in most cases also computed in decimilligrams per hour per 100 grams of shellfish and in some cases in decimilligrams per hour per I gram of the dried weight of the total shell contents of the organism.

A formula for the first of these three computations might be expressed, therefore, as follows:

$$
A=W \frac{a^{\prime}-a^{\prime \prime}}{100} \cdot \frac{60}{t}
$$

where $A$ is the decimilligrams of $O$ used per hour, $W$ the weight, in grams, of water in the desiccator, $a^{\prime}$ the parts per million of oxygen in the first sample and $a^{\prime \prime}$ in the second sample, and $t$ is the time of the experiment in minutes.

Throughout the experiments it was found necessary to observe the animal at frequent intervals, and if the shells closed up to discard the experiment, or if the shells closed only after a considerable number of minutes had elapsed to terminate the experiment immediately. This precaution was necessary because, as is well known, certain of the shellfish used in this work can close water tight and in that condition take from the 
water, as will be shown below, no oxygen except the very small amount absorbed by their shells.

It appeared early in the work that constancy of results was exceedingly difficult to obtain. This was due to a variety of causes, chief of which was the great variability in the openness of the shells, for not only could the oyster or clam entirely or at least obviously close so that the experiment had to be terminated, but it could partially and unnoticeably close or indeed fail to open wide even from the beginning of the experiment. For the oyster, at least, the author succeeded in demonstrating this by graphic records. One shell of an oyster was connected by tying a string to the projections with a lightly balanced lever recording on a slow kymograph. As soon as the oyster in a water bath at a temperature between $\mathrm{I} 8^{\circ}$ and $20^{\circ} \mathrm{C}$. had opened somewhat, the kymograph was started and the temperature of the bath raised at the rate of $\mathrm{I}^{\circ} \mathrm{C}$. in about eight minutes. The oysters remained fairly well open with brief periods of partial closure as the temperature increased to about $22^{\circ} \mathrm{C}$. At that point there invariably appeared in the three individuals observed periods of maximum openness lasting as long as no disturbing factor intervened. Sufficient stimulus for partial closure, however, was likely to occur frequently. A light tap on the table or water bath, a heavy step in the room, the slamming of a door in a neighboring part of the building, or, indeed, any slight jar was surely registered by some movement of the shell. As the temperature increased up to about $26^{\circ}$ or $27^{\circ} \mathrm{C}$., the effect of these stimuli was much less marked. The oysters then maintained their maximum openness very persistently. Between $27^{\circ}$ and $30^{\circ}$ a tendency to very slow and incomplete opening after closure was noticeable, indeed no maximum openness was seen. At about $30^{\circ}$ or $3 \mathrm{I}^{\circ} \mathrm{C}$, , the oysters closed tightly, even if no mechanical stimulus was given.

As the kymograph method served to detect movements of the shell not noticeable to unaided observation and also slight openings of the shell not otherwise visible, these experiments were an aid to planning and interpreting measurements of oxygen utilization. They showed that below $19^{\circ} \mathrm{C}$. and above $26^{\circ} \mathrm{C}$. observations on the opened oyster were impossible, that temperature must be maintained constant throughout the experiment, and mechanical disturbances must be avoided as far as possible. A further source of difficulty had also to be overcome. When the oyster excreted it closed violently, to drive the fecal matter out of the shell. If the position of the animal rendered complete excretion difficult, closures were frequently repeated, and sometimes the oyster shut up tightly. It was necessary, therefore, to lay the oyster in the desiccator tipped so that the more concave side of the shell, where excretion occurs, would be lower than the other.

In spite of all precautions, however, perfectly consistent results could not always be obtained. Under the same or comparable conditions of temperature, oxygen content of the water, and physical conditions, the same individual would sometimes in different experiments give results disagreeing beyond the limits of the calculated, probable, experimental error. Various observations make it seem likely that the nutritive condition of the individual could account for some, at least, of these discrepancies. Thus, after 
remaining at a high temperature (e. g., $24^{\circ}-26^{\circ} \mathrm{C}$.) for some time, the oxygen requirement at a slightly lower temperature would tend to be greater than if the shellfish had been at a lower temperature before the experiment. If an oyster had been out of water for some time before the measurement, more oxygen would be used, generally, than if the specimen were left in the aquarium until the time of the experiment. After the shellfish had been kept in the aquarium some weeks they tended to use less oxygen than when taken recently from their native environment. Exceptionally an individual would show a high utilization of oxygen out of proportion to previous measurements and lasting for several days. As many of the interfering conditions as possible were, of course, eliminated, but still it seemed necessary to make a considerable number of experiments and draw conclusions only from averages. More than 350 measurements were made under various conditions on three types of lamellibranchs-the oyster (Ostrea virginica), the soft-shell or long clam (Mya arenaria), and the quahog or round clam (Venus mercenaria).

\section{RESULTS.}

OXYGEN REQUIREMENTS OF THE OYSTER.

Three series of experiments, each made on a limited number of individuals, are submitted. Although the results can scarcely be taken to show any seasonal variation, they are grouped, for convenience, according to the time they were carried out. In table $I$ are the results of measurements taken during July, I9II; in table II, those of July and August, 1912; and in table III are results obtained during the latter part of August, 1912.

In the experiments of table I definite temperatures were not previously chosen and carefully adhered to as in the later work. The results, therefore, are here grouped for comparison as follows: All measurements taken at temperatures between $20^{\circ}$ and $21.3^{\circ} \mathrm{C}$. appear in one column, those at $21.5^{\circ}$ to $23.5^{\circ} \mathrm{C}$. in another, and those between $26^{\circ}$ and $28^{\circ} \mathrm{C}$. in a third. Where two or more experiments were made with one oyster at temperatures within a given range the average of the results is placed in parentheses. . In the last three columns are the averages of comparable experiments computed as the decimilligrams of oxygen used per hour per 100 grams of oyster. By weight of oyster is meant in this and other tables not otherwise specified the weight in grams taken after it was closed under water, wiped as dry as possible with a towel, and left to dry in the air not more than half an hour. Such weighings were shown by duplication to be accurate to within two-tenths of a gram.

In table II are the results of experiments performed at definite chosen temperatures so controlled that the variation was not more than half a degree centigrade in any single experiment. The first five columns of results show the decimilligrams of oxygen used per hour at five temperatures by nine oysters. The averages of all comparable experiments are put in parentheses. The last five columns contain the averages, expressed in decimilligrams, of the oxygen used per hour per 100 grams of oysters. 
TABLE I.-OXYGEN USED BY OYSTERS.

NorE.-Figures in parentheses are averages of experiments under approximately uniform conditions.

\begin{tabular}{|c|c|c|c|c|c|c|}
\hline \multirow{2}{*}{$\begin{array}{l}\text { Weight } \\
\text { of whole } \\
\text { oyster. }\end{array}$} & \multicolumn{3}{|c|}{$\begin{array}{l}\text { Decimilligrams of oxygen used } \\
\text { per hour. }\end{array}$} & \multicolumn{3}{|c|}{$\begin{array}{l}\text { Average decimilligrams of oxygen } \\
\text { per hour per yoo grams of oyster. }\end{array}$} \\
\hline & $\begin{array}{l}\text { At } 20^{\circ} \text { to } \\
2 \mathbf{1} \cdot 3^{\circ} \mathrm{C} \text {. }\end{array}$ & $\begin{array}{c}\text { At } 21 \cdot 5^{\circ} \text { to } \\
23.5^{\circ} \mathrm{C}\end{array}$ & $\begin{array}{l}\text { At } 26^{\circ} \text { to } \\
28^{\circ} \mathrm{C}\end{array}$ & $\begin{array}{l}\text { At } 20^{\circ} \text { to } \\
21.3^{\circ} \mathrm{C} \text {. }\end{array}$ & $\begin{array}{l}\text { At } 21.5^{\circ} \text { to } \\
23.5^{\circ} \mathrm{C}\end{array}$ & $\begin{array}{l}\text { At } 26^{\circ} \text { to } \\
28^{\circ} \mathrm{C} \text {. }\end{array}$ \\
\hline $\begin{array}{c}\text { Grams. } \\
42.0\end{array}$ & & $\begin{array}{r}5.6 \\
9.0 \\
7.8 \\
6.8 \\
(7.3)\end{array}$ & & & 17.4 & \\
\hline 56.6 & .... & $\begin{array}{l}\text { Ir. } \\
7.6 \\
(9 \cdot 7)\end{array}$ & & & $x 7.2$ & \\
\hline 85.0 & $\begin{array}{c}9.4 \\
14.7 \\
14.0 \\
(12.7)\end{array}$ & & $\begin{array}{l}19.3 \\
18.8 \\
(19.1)\end{array}$ & 14.9 & .. & 22.4 \\
\hline 106.0 & $\begin{array}{l}10.1 \\
15.6 \\
(12.8)\end{array}$ & Ig. 4 & $\begin{array}{c}22.9 \\
22.9 \\
26.2 \\
(24.0)\end{array}$ & 12.8 & 18.3 & 22.6 \\
\hline 113.0 & 14.6 & $\begin{array}{l}18.2 \\
16.1 \\
(17.1)\end{array}$ & & 12.9 & 15.1 & \\
\hline 127.0 & $\begin{array}{r}12.7 \\
13.6 \\
15.7 \\
(14.0)\end{array}$ & $\begin{array}{c}2 \mathrm{I} .8 \\
2 \mathrm{I} .5 \\
19.0 \\
2 \mathrm{I} .2 \\
(20.9)\end{array}$ & 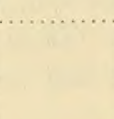 & II. I & 16. 5 & \\
\hline$x 41.0$ & ...... & $\begin{array}{l}19.0 \\
18.0 \\
\text { (18.5) }\end{array}$ & & & 13.1 & $\cdots$ \\
\hline
\end{tabular}




\section{1. \\ OXYGEN REQUIREMENTS OF SHELLFISH.}

TABIE II.-OXYGEN USED BY OYSTERS.

NoTE.-Figures in parentheses are averages of measurements under approximately uniform conditions.

\begin{tabular}{|c|c|c|c|c|c|c|c|c|c|c|}
\hline \multirow{2}{*}{$\begin{array}{l}\text { Weight } \\
\text { of whole } \\
\text { oyster. }\end{array}$} & \multicolumn{5}{|c|}{ Decimilligrams of oxygen used per hour. } & \multicolumn{5}{|c|}{$\begin{array}{c}\text { Decimilligrams of oxygen used per hour per } 100 \\
\text { grams. }\end{array}$} \\
\hline & $\begin{array}{l}\text { At } 19.5^{\circ} \\
\text { to } 20^{\circ} \mathrm{C} \text {. }\end{array}$ & $\begin{array}{l}\text { At } 2 I^{\circ} \text { to } \\
2 I .5^{\circ} \mathrm{C}\end{array}$ & $\begin{array}{l}\text { At } 22^{\circ} \text { to } \\
22.5^{\circ} \mathrm{C}\end{array}$ & $\begin{array}{l}\text { At } 24^{\circ} \text { to } \\
24.5^{\circ} \mathrm{C} \text {. }\end{array}$ & $\begin{array}{l}\text { At } 26^{\circ} \text { to } \\
26.5^{\circ} \mathrm{C} \text {. }\end{array}$ & $\begin{array}{l}\text { At } 19.5^{\circ} \\
\text { to } 20^{\circ} \mathrm{C} \text {. }\end{array}$ & $\begin{array}{l}\text { At } 2 I^{\circ} \text { to } \\
2 \mathrm{I}-5^{\circ} \mathrm{C} .\end{array}$ & $\begin{array}{c}\text { At } 22^{\circ} \text { to } \\
22.5^{\circ} \mathrm{C} \text {. }\end{array}$ & $\begin{array}{l}\text { At } 24^{\circ} \text { to } \\
24.5^{\circ} \mathrm{C}\end{array}$ & $\begin{array}{l}\text { At } 26^{\circ} \text { to } \\
26.5^{\circ} \mathrm{C} \text {. }\end{array}$ \\
\hline $\begin{array}{c}\text { Grams. } \\
42.0\end{array}$ & $\begin{array}{c}7.6 \\
9.8 \\
(8.7)\end{array}$ & $\begin{array}{r}12.3 \\
13.8 \\
(13.1)\end{array}$ & $\begin{array}{r}10.3 \\
13.9 \\
(12.2)\end{array}$ & 14.6 & $\begin{array}{c}13.4 \\
14.9 \\
11.2 \\
(13.1)\end{array}$ & 20. 7 & $3 \mathrm{r} .0$ & 29.1 & 34.8 & 35.3 \\
\hline 51.0 & $\begin{array}{c}11.6 \\
10.7 \\
11.8 \\
(11.3)\end{array}$ & $\begin{array}{r}9.3 \\
11.4 \\
9.6 \\
6.2 \\
(9.6)\end{array}$ & $\begin{array}{l}13.7 \\
11.5 \\
(11.6)\end{array}$ & $\begin{array}{c}12.6 \\
12.7 \\
(12.65)\end{array}$ & 13.6 & 22.2 & 17.9 & 22.8 & 24.8 & 25.: \\
\hline 66.5 & $\begin{array}{r}\text { I5. I } \\
9.4 \\
10.5 \\
9.1 \\
(11.2)\end{array}$ & $\begin{array}{r}16.0 \\
9.9 \\
16.1 \\
14.0 \\
(14.0)\end{array}$ & $\begin{array}{c}I 5.5 \\
\text { IL.8 } \\
(13.7)\end{array}$ & 16.0 & $\begin{array}{r}18.6 \\
17.2 \\
(17.9)\end{array}$ & 16.9 & 21.0 & 20.6 & $24=I$ & 26.9 \\
\hline 76.0 & $\begin{array}{l}\text { II. } 5 \\
\text { I4.0 } \\
(I 2.7)\end{array}$ & $\begin{array}{c}13.9 \\
15.3 \\
14.2 \\
(14.5)\end{array}$ & $\begin{array}{c}25.3 \\
12.8 \\
(14.05)\end{array}$ & $\begin{array}{l}\text { I5. } \\
20.5 \\
\text { I6.2 } \\
(37.5)\end{array}$ & $\begin{array}{l}23.5 \\
20.9 \\
24.5 \\
20.7 \\
(22.4)\end{array}$ & 16. 7 & 19.0 & 18.5 & 23.0 & 29.5 \\
\hline $97 \cdot 4$ & 23.4 & 14.6 & $\cdots$ & 18.0 & 22. I & I3. 8 & 15.0 & 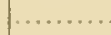 & I8. 5 & 22.7 \\
\hline I 23.0 & $\begin{array}{c}13.7 \\
17.8 \\
(15.75)\end{array}$ & ......... & $\begin{array}{r}17.9 \\
25.9 \\
18.6 \\
18.4 \\
(20.2)\end{array}$ & $\begin{array}{c}25.9 \\
19.8 \\
(22.8)\end{array}$ & 24.8 & I2. 3 & . & 15.7 & 37.8 & $=9.4$ \\
\hline 147.0 & $\begin{array}{c}16.0 \\
19.4 \\
(17.7)\end{array}$ & $\begin{array}{r}18.4 \\
18.2 \\
(18.3)\end{array}$ & $\begin{array}{c}20.4 \\
19.3 \\
(19.8)\end{array}$ & $\begin{array}{r}20.8 \\
21.9 \\
(21.3)\end{array}$ & $\begin{array}{c}26.6 \\
26.0 \\
(26.3)\end{array}$ & I2. I & 12.5 & 13.5 & I4. 5 & 17.9 \\
\hline 24.4 .0 & $\begin{array}{r}28 . I \\
22.3 \\
(20.2)\end{array}$ & $\begin{array}{c}23 \cdot 5 \\
25 \cdot 7 \\
(24 \cdot 6)\end{array}$ & $\begin{array}{c}35.6 \\
25.7 \\
(30.1)\end{array}$ & $\begin{array}{c}30.0 \\
26.1 \\
24.0 \\
(26.7)\end{array}$ & 35.1 & 8.3 & 10. $x$ & 12.3 & $5 \mathrm{~L} .0$ & 54.4 \\
\hline 252.0 & 19.0 & $\begin{array}{c}29.1 \\
29.5 \\
28.4 \\
20.8 \\
(25.2)\end{array}$ & $\begin{array}{c}27.4 \\
24.8 \\
(26 . I)\end{array}$ & $\begin{array}{c}28.7 \\
30.7 \\
(29.7)\end{array}$ & 37.0 & $7 \cdot 3$ & 9.6 & 10.0 & II. 3 & I 4.5 \\
\hline Average & & 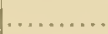 & & &  & 14.5 & 17.0 & 17.8 & 20.0 & 23.5 \\
\hline
\end{tabular}

In table III are the results of measurements at four chosen temperatures on four oysters. These experiments were all done within a few days after the oysters were taken from the beds and therefore serve to some extent as a control on the condition of the oysters used in the other series. The first columns of results show the decimilligrums of oxygen used per hour at the designated temperatures. The averages of comparable experiments are put in parentheses. The figures in the next four columns are obtained by computing the arerages of the oxygen utilization per roo grams of oyster. In the next column is the weight, in grams, of the shell contents of each oyster when dried to constant weight. The last four columns show arerage decimilligrams of oxygen used per gram of dried substance. The figures in these columns were corrected for the 
oxygen used by the shells. The shells of each oyster were at the end of the observations carefully cleaned in sea water and then used for two or three measurements of their oxygen-absorbing power at different temperatures. As these results were obtained under the same conditions as those expressed in table III, they represent a fair estimate of the oxygen absorbed by the shells during measurements with the intact oyster. There is reason, as will be shown below, to believe that oxygen removed from the water in this way is not utilized by the active tissues of the oyster. It secms reasonable, therefore, to subtract the amount (measured or computed) of oxygen utilized by the shells from that used by the whole oyster before computing the oxygen requitements per gram of dried tissue.

TABLE III.-OXYGEN USED BY OYSTERS.

NoTe.-Figures in parentheses are averages of measurements under approximately uniform conditions.

\begin{tabular}{|c|c|c|c|c|c|c|c|c|c|c|c|c|c|}
\hline \multirow{2}{*}{$\begin{array}{l}\text { Weight, } \\
\text { whole } \\
\text { oyster. }\end{array}$} & \multicolumn{4}{|c|}{$\begin{array}{c}\text { Decimilligrams of oxygen used } \\
\text { per hour. }\end{array}$} & \multicolumn{4}{|c|}{$\begin{array}{c}\text { Averages of same per hour per } \\
\text { I00 grams. }\end{array}$} & \multirow{2}{*}{$\begin{array}{l}\text { Weight, } \\
\text { dried } \\
\text { oyster. }\end{array}$} & \multicolumn{4}{|c|}{$\begin{array}{l}\text { Average decimilligrams used per } \\
\text { hour per gram of dried weight. }\end{array}$} \\
\hline & $\begin{array}{c}\text { At } \\
20^{\circ} \text { to } \\
20.5^{\circ} \mathrm{C}\end{array}$ & $\begin{array}{c}\mathrm{At} \\
22^{\circ} \text { to } \\
22.5^{\circ} \mathrm{C}\end{array}$ & $\begin{array}{c}\mathrm{At} \\
24^{\circ} \text { to } \\
24.5^{\circ} \mathrm{C}\end{array}$ & $\begin{array}{c}\mathrm{At} \\
26^{\circ} \text { to } \\
26.5^{\circ} \mathrm{C}\end{array}$ & $\begin{array}{c}\text { At } \\
20^{\circ} \mathrm{to} \\
20.5^{\circ} \mathrm{C}\end{array}$ & $\begin{array}{c}\text { At } \\
22^{\circ} \text { to } \\
22.5^{\circ} \mathrm{C}\end{array}$ & $\begin{array}{c}\mathrm{At} \\
24^{\circ} \mathrm{to} \\
24 \cdot 5^{\circ} \mathrm{C}\end{array}$ & $\begin{array}{c}\text { At } \\
26^{\circ} \text { to } \\
26.5^{\circ} \mathrm{C} \text {. }\end{array}$ & & $\mid \begin{array}{c}\text { At } \\
20^{\circ} \mathrm{to} \\
20.5^{\circ} \mathrm{C}\end{array}$ & $\begin{array}{c}\text { At } \\
22^{\circ} \text { to } \\
22.5^{\circ} \mathrm{C}\end{array}$ & $\begin{array}{c}\mathrm{At} \\
24^{\circ} \text { to } \\
24.5^{\circ} \mathrm{C}\end{array}$ & $\begin{array}{c}\mathrm{At} \\
26^{\circ} \mathrm{tc} \\
26.5^{\circ} \mathrm{C}\end{array}$ \\
\hline $\begin{array}{l}\text { Grams. } \\
47.8\end{array}$ & 10. 6 & $\left.\begin{array}{r}12.2 \\
14 \cdot-1 \\
\left(x_{3} \cdot 1\right.\end{array}\right)$ & 14.2 & 17.1 & 22.2 & 27.4 & 29.7 & $35 \cdot 7$ & $\begin{array}{c}\text { Grams. } \\
1.15\end{array}$ & $7 \cdot 92$ & $9 \cdot 74$ & 10.40 & $I 2.90$ \\
\hline 73. 5 & $x 6.6$ & $\begin{array}{c}20.0 \\
17 \cdot 5 \\
(18-3)\end{array}$ & $\begin{array}{l}23.1 \\
\text { IS. } 3 \\
(20.7)\end{array}$ & 22.0 & 22.6 & 25.0 & 28.2 & 30.0 & I. 66 & 8.20 & 8.61 & 9.43 & 9. 56 \\
\hline 553.0 & Ig. 4 & 22.4 & $\begin{array}{r}21.4 \\
21.7 \\
24.5 \\
(22.5)\end{array}$ & $\begin{array}{r}25.2 \\
25.9 \\
(25.5)\end{array}$ & 12.7 & 14.6 & I4. 7 & 16.6 & 2.36 & 5.28 & 6.78 & c. 56 & 7.15 \\
\hline$x 73.0$ & 23.5 & $\begin{array}{r}24.5 \\
24 \cdot 7 \\
(: 2 .(1) \\
\end{array}$ & $\begin{array}{r}29.2 \\
30.8 \\
(10.0)\end{array}$ & $\begin{array}{l}39.0 \\
34.2 \\
(i 6.0)\end{array}$ & 13.6 & $14 \cdot 2$ & $17 \cdot 3$ & 28.2 & 3.64 & 3.49 & $4 . \infty$ & $4 \cdot 53$ & 6.10 \\
\hline Average. & 17.5 & 19. 7 & 21.9 & $25 \cdot 3$ & 17.8 & 20.3 & 23.5 & 25.9 & $\ldots$ & $6.4 \mathrm{I}$ & 7.28 & 7.73 & 8. 94 \\
\hline
\end{tabular}

A graphic representation of the oxygen utilization of oysters at different temperatures is given on page 217 . The ordinates represent decimilligrams of oxygen used per hour and the abscissæ are degrees Centigrade. The full lines represent measurements on intact oysters. Curve I is constructed from the averages of the oxygen utilization per hour per 100 grams in experiments on nine oysters as summarized in table II. Curve II is constructed from similar averages of experimental results on four oysters as shown in table III. Curve III is based on the same results used for curve Il, but represents the averages of oxygen used per hour per gram of dried shell contents. The relationship between oxygen and temperature is apparently a simple one. The interrupted lines represent measurements on empty oyster shells showing the decimiligrams of oxygen used per hour by shells as recorded in table IV. Curves $a, b, c$, and $d$ refer, respectively, to shells weighing $47.8,73.4, I_{53}$, and I6I grams. The effect of temperature on the three larger shells scems to be fairly constant; their curves are parallel. 'The discrepancy in the smallest shell may be due to experimental error as so few determinations were made. 


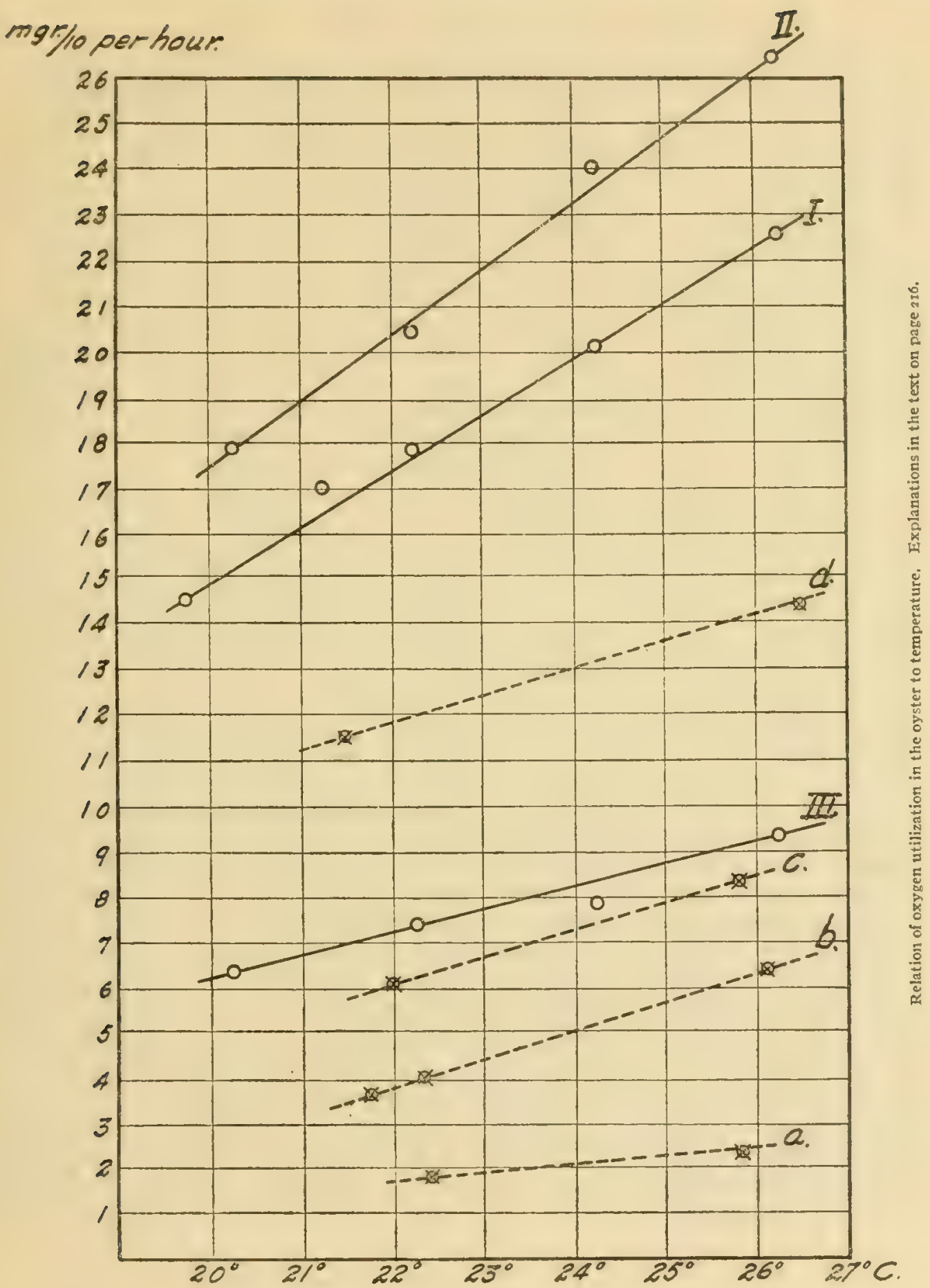




\section{NONUTILIZATION OF OXYGEN BY CLOSED OYSTERS.}

Since oysters can close absolutely water tight, it seemed possible that under such conditions they would take in no oxygen. The very small oxygen requirements of voluntarily closed individuals could not, however, be interpreted as proof of this because when the oyster appears to be closed it may be slightly and invisibly open. This was proved by graphic records. To insure closure throughout an observation it was necessary, therefore, to use some artificial closing device. Several clamps were tried. An ordinary surgeon's artery clamp was found to be most satisfactory. If clamps without imperfections, carefully vaselined, were used, they did not appreciably rust during the experiment and withdrew from the water only a small and constant quantity of oxygen. As control experiments the oxygen absorption of empty shells of oysters about the same size as the one observed was measured. The control shells were fastened together by a clamp duplicating the one used on the oyster. Water had some access to the interior of the empty shells through nicks in their edges. On their immersion in water all air was driven from them. In many experiments controls were deferred until the same oyster could be emptied and its shells used for control measurements.

The results of a number of determinations are given in table $v$. It is seen that in every case the experiment and its control are in close agreement, as the difference is within the limit of experimental error except in the case of the largest oyster used. Even these differences, however, show a larger oxygen absorption by the empty shells than by the closed intact oysters. That the slight oxygen disappearance does not represent a respiratory intake by diffusion through the shells is indicated not only by the controls but by the observation that a two hours' exposure of the clamped oyster does not cause twice the oxygen absorption observed during one hour. Thus in one experiment a clamped oyster used 1.83 decimilligrams of oxygen in one hour, but 3.01 in two hours, while another, which used I.70 decimilligrams in one hour, required 2.80 for two hours.

The explanation of the constant slight absorption of oxygen by clamped oysters and empty shells was not positively determined, but would seem to lie in several causes. Bacteria and various marine vegetative growths on the shells were first considered as possible oxygen users. Oyster shells that had been soaked 16 hours in 80 per cent alcohol and then carefully scrubbed and dried, did, indeed, show a diminished oxygen absorbing capacity, in one case lowered from 5.25 decimilligrams per hour before the alcohol treatment to 4.68 after it, and in another, from 3.08 to 2.34 . This indicates that foreign growths do not account for all the oxygen absorption, and, indeed, it was found that the cleanest and most carefully sterilized shells took oxygen from the water.

An adsorption effect of porous substances on dissolved oxygen suggested itself as another possibility. It was found that porcelain evaporating dishes about the size of oysters showed equivalent oxygen absorbing powers. Corks had the same capacity. Water containing medium sized corls lost 2.34 decimilligrams of oxygen per hour, while in a control experiment water alone lost only 0.26 decimilligram, which is within the limit of experimental error. 
TABLE IV.-OXYgen ABSORBED BY EMPTy OXSTER SHELLS.

\begin{tabular}{|c|c|c|c|c|c|c|c|c|c|}
\hline Weight of whole oyster in grams. & 47.8 & 47.8 & 73.4 & $73 \cdot 4$ & 73.4 & 153 & $\mathbf{x} 53$ & $16 x$ & $16 \mathrm{I}$ \\
\hline $\begin{array}{l}\text { Temperature of experiment in degreed centigrade.. } \\
\text { Oxygen absorbed per hour in mgr/to.............. }\end{array}$ & $\begin{array}{r}22.4 \\
7.9\end{array}$ & $\begin{array}{r}25.8 \\
2.4\end{array}$ & $\begin{array}{r}21.7 \\
3.6\end{array}$ & $\begin{array}{r}22 \cdot 3 \\
4 \cdot I\end{array}$ & $\begin{array}{r}26.1 \\
6.3\end{array}$ & $\begin{array}{r}22.0 \\
6.1\end{array}$ & $\begin{array}{r}25.8 \\
8.3\end{array}$ & $\begin{array}{l}21 \cdot 5 \\
2 I \cdot 5\end{array}$ & $\begin{array}{l}26.5 \\
14.4\end{array}$ \\
\hline
\end{tabular}

TABLE V.-OXYgen ABSORBED By Closeid Oysters.

\begin{tabular}{|c|c|c|c|}
\hline $\begin{array}{l}\text { Weight of } \\
\text { oyster. }\end{array}$ & $\begin{array}{l}\text { Tempera- } \\
\text { ture of } \\
\text { experi- } \\
\text { ment. }\end{array}$ & $\begin{array}{l}\text { Oxygen } \\
\text { used per } \\
\text { hour. }\end{array}$ & Description of control experiment. \\
\hline $\begin{array}{l}45 \text { grams... } \\
\text { Control... } \\
50 \text { grams... } \\
\text { Control.... } \\
66.5 \text { grams.. } \\
\text { Control..... } \\
\text { Control..... } \\
66.5 \text { grams.. } \\
\text { Control..... } \\
128 \text { grams.. } \\
\text { Control.... } \\
147 \text { grams.. } \\
\text { Control..... } \\
244 \text { grams.. } \\
\text { Control..... } \\
262 \text { grams.. } \\
\text { Control.... } \\
244 \text { grams.. } \\
\text { I28 grams.. } \\
66.5 \text { grams.. } \\
76 \text { grams... }\end{array}$ & $\begin{array}{l}{ }^{\circ} \mathrm{C} . \\
22.0 \\
22.0 \\
22.0 \\
22.0 \\
23.2 \\
21.0 \\
23.2 \\
20.5 \\
20.5 \\
20.5 \\
20.5 \\
20.5 \\
20.5 \\
20.5 \\
21.0 \\
20.5 \\
21.0 \\
27.5 \\
27.5 \\
27.5 \\
27.5\end{array}$ & $\begin{array}{r}\mathrm{Mgr} / \mathrm{to} . \\
\text { I. } 70 \\
I .70 \\
I .83 \\
I .83 \\
2.04 \\
1.92 \\
2.58 \\
1.41 \\
I .48 \\
I .79 \\
I .92 \\
1.74 \\
I .62 \\
1.70 \\
2.34 \\
3.39 \\
4.68 \\
3.47 \\
2.36 \\
3.49 \\
2.80\end{array}$ & $\begin{array}{l}\text { Empty shells of same oyster with artery clamp. } \\
\text { Do. } \\
\text { Do. } \\
\text { Empty shells of oyster weighing } 45 \text { grams with clamp. } \\
\text { Empty shells of oyster weighing } 5 \text { I grams with clamp. } \\
\text { Empty shells of same oyster with artery clamp. } \\
\text { Do. } \\
\text { Do. } \\
\text { Do. } \\
\text { Control experiments not made. }\end{array}$ \\
\hline
\end{tabular}

RESISTANCE; OF OYSTERS TO LACK OF OXYGEN.

A series of experiments was undertaken to find out the minimum oxygen supply that would maintain an oyster alive. The sea water surrounding an oyster in a vacuum desiccator was as far as possible rendered oxygen free by boiling at room temperature under diminished pressure for half an hour. It was found in two trials that sea water alone when so treated and kept twelve hours in the closed desiccator still had an oxygen content less than 0.5 of a part per million. An oyster kept under these circumstances four days showed no ill effects. Another was kept thus three days, transferred to a second desiccator of exhausted sea water, which was quickly again pumped out, and was then kept four days further in the oxygen poor medium. The shells then had some black deposits on them indicative of incipient anaerobic putrefaction. The sea water on opening the desiccator was found absolutely oxygen free. The oyster, however, seemed unimpaired, and after remaining in the aquarium some time was opened and found apparently entirely normal. As each desiccator held about $\mathrm{I}, 200 \mathrm{c}$. c. and the oxygen content of the water in each case was at the most 0.5 of a part per million, the oxygen available to the oyster might be estimated as 1.2 milligrams plus the small amount obtained during the transfer from one desiccator to the other. If we disregard the latter source because the oyster was tight closed at the time, only r.2 milligrams of oxygen were used during seven days. 
In another experiment an oyster was kept three days in the first desiccator full of pumped-out water, three days in the second, two days in the third, two days in the fourth, and two days in the fifth. By that time it was black and unable to close properly. After a few hours in the aquarium it showed disintegration, so that twelve days of life in oxygen-poor water proved fatal. Time and facilities for carrying out many of these experiments were missing, although the seven-day experiment was practically duplicated by one in which an oyster was kept in the same desiccator full of water six days with no ill effects. That the fatal effect of a twelve days' exposure was not due to insufficient renewal of the water was shown by control experiments in which several oysters were kept in the same water during fourteen days while air was bubbled through it. The oysters survived this treatment uninjured.

\section{OXYGEN REQUIREMENTS OF CLAMS.}

Measurements on clams were made by the same method used for oysters. The results of successful experiments are embodied in table vi. They show a general agreement with measurements on oysters. The amount of oxygen used by ciams weighing about 60 grams is somewhat higher per 100 grams than that used by an oyster of about the same weight and observed at the same temperature. Computed per gram of dried shell contents, however, the oxygen requirements of the clam seem somewhat smaller than those of the oyster. Here, as with oysters, the amount of oxygen used is more or less proportional to increase in the temperature, though sufficient data to show a simple relationship were not obtained. In this case, also, the oxygen requirement per gram is less in the larger individual than in the smaller, again like the oyster.

TABLE VI,-OXYGEN USED BY CLAMS.

NoTE. - Figures in parentheses are averages of measurements under approximately uniform conditions.

\begin{tabular}{|c|c|c|c|c|c|c|c|c|c|c|}
\hline \multirow{2}{*}{$\begin{array}{l}\text { Weight } \\
\text { whole } \\
\text { clam. }\end{array}$} & \multicolumn{3}{|c|}{$\begin{array}{l}\text { Decimilitigrams of oxy gen used } \\
\text { per hour. }\end{array}$} & \multicolumn{3}{|c|}{$\begin{array}{l}\text { Averages of same per hour per } \\
\text { s00 grams. }\end{array}$} & \multirow{2}{*}{$\begin{array}{l}\text { Weight } \\
\text { dried } \\
\text { clam. } \\
\text {. }\end{array}$} & \multicolumn{3}{|c|}{$\begin{array}{l}\text { Average mgt/xo used per hour } \\
\text { per gram, dried weight. }\end{array}$} \\
\hline & $\begin{array}{l}\text { At } 20^{\circ} \text { to } \\
2 I^{\circ} \mathrm{C}\end{array}$ & $\begin{array}{l}\text { At } 22^{\circ} \text { to } \\
22.5^{\circ} \mathrm{C} \text {. }\end{array}$ & $\begin{array}{l}\text { At } 24^{\circ} \text { to } \\
24.5^{\circ} \mathrm{C}\end{array}$ & $\begin{array}{l}\text { At } 20^{\circ} \text { to } \\
21^{\circ} \mathrm{C}\end{array}$ & $\begin{array}{l}\text { At } 22^{\circ} \text { to } \\
22.3^{\circ} \mathrm{C} \text {. }\end{array}$ & $\begin{array}{l}\text { At } 24^{\circ} \text { to } \\
24.5^{\circ} \mathrm{C}\end{array} \mid$ & & $\begin{array}{l}\text { At } \approx 0^{\circ} \text { to } \\
2 I^{\circ} \mathrm{C} \text {. }\end{array}$ & $\begin{array}{l}\text { At } 22^{\circ} \text { to } \\
22.5^{\circ} \mathrm{C} \text {. }\end{array}$ & $\begin{array}{l}\text { At } 24^{\circ} \text { to } \\
24.5^{\circ} \mathrm{C} \text {. }\end{array}$ \\
\hline $\begin{aligned} \text { Grams. } \\
7.0\end{aligned}$ & $\begin{array}{r}1.2 \\
3.0 \\
(2.1)\end{array}$ & & & $=9.0$ & & & Grams. & & & \\
\hline 19.5 & $5 \cdot 19$ & 9.7 & IS. I & 26.7 & $49 \cdot 7$ & $77 \cdot 4$ & J. 32 & 3.93 & 2.35 & $11-4$ \\
\hline 21.0 & $\begin{array}{l}9.2 \\
6.7 \\
(7.9)\end{array}$ & & & 26.9 & & & & & & \\
\hline 28.0 & 8. 2 & & & 29.3 & & & & & & \\
\hline $5 \pi .0$ & $\begin{array}{l}\text { II. } \\
\text { I2.4 } \\
\text { (II. } 7 \text { ) }\end{array}$ & & & 20.7 & & & & & & \\
\hline 57.5 & n....... & 57.2 & 30.0 & $1 \ldots \ldots \ldots$ & 30.0 & 52.2 & 3.97 & & $4 \cdot 34$ & $7 \cdot 55$ \\
\hline 60.0 & $\ldots \ldots$ & 19. I & & ..... & 35.9 & & & & & \\
\hline 63.0 & $\begin{array}{c}17.7 \\
15.2 \\
(16.4)\end{array}$ & & & 25.8 & .. & & & & 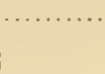 & 1 \\
\hline
\end{tabular}


TABi, VII.-OXYgen Absorbed by Closed Quahogs.

\begin{tabular}{|c|c|c|c|c|c|c|c|c|c|}
\hline Weight of quahog in grams... & Iso & 150 & $9 \mathrm{r}$ & $9 \mathrm{I}$ & 246 & $246 a$ & $150^{a}$ & $I 50 b$ & 928 \\
\hline 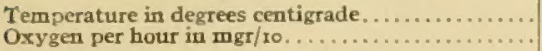 & $\begin{array}{r}24.0 \\
.37\end{array}$ & $\begin{array}{r}24.0 \\
.25\end{array}$ & $\begin{array}{r}24 \cdot 0 \\
.38\end{array}$ & $\begin{array}{r}23.0 \\
.25\end{array}$ & $\begin{array}{r}24 \cdot 3 \\
.23\end{array}$ & $\begin{array}{l}23.0 \\
4.60\end{array}$ & $\begin{array}{l}23.0 \\
4 \cdot 30\end{array}$ & $\begin{array}{l}23.6 \\
2.43\end{array}$ & $\begin{array}{l}23.5 \\
2.95\end{array}$ \\
\hline
\end{tabular}

a Voluntarily closed but not clamped.

Measurements on empty shells alone.

\section{OXYGEN ABSORPTION OF CLOSED CLAMS.}

Only one experiment was made in this connection. A medium-sized clam was closed by an artery clamp over the siphon end of the shells. As a control, empty shells of an oyster of the same size similarly clamped were used. The live clam absorbed 2.68 decimilligrams of oxygen per hour at a temperature of $23.5^{\circ} \mathrm{C}$, while the shell took 2.58 . This indicates that the clam, like the oyster, has little or no opportunity to obtain oxygen when the shell is not open. Further observations incidentally made confirm this conclusion. A medium-sized clam which visibly failed to open throughout an experiment to determine its oxygen requirements took only 2.44 decimilligrams of oxygen from the water in an hour. Other similar results were obtained.

\section{OXYGEN REQUIREMENTS OF QUAHOGS.}

Great difficulty was experienced in measuring the oxygen utilization of quahogs, because they seldom opened for any length of time under the conditions of experimentation. As a result of this, only a few measurements that could be considered reliable were obtained. It was found necessary to place the specimen in sea water in the desiccator a long time before the experiment, usually the night before, in order to have it open at the time of observation. Handling or moving caused it to close and stay closed for some hours.

The few successful observations showed a rather low oxygen utilization. One specimen weighing 91 grams used, at $24^{\circ} \mathrm{C}$., IO.I decimilligrams of oxygen in one hour, 10.8 in another measurement, and 6.4 in a third. Another quahog, weighing 150 grams, used, at $24^{\circ} \mathrm{C}$, 7.8 decimilligrams per hour, and a large one (470 grams) used 22.4 decimilligrams per hour. Many other measurements were attempted, but owing to closure soon after the beginning of observation were unreliable. The oxygen requirements in proportion to the dried weight showed a still greater discrepancy in comparison with similar computations for the oyster. The dried weights of the shell contents of the first two quahogs observed were, respectively, 2.22 grams and 3.86 grams. The oxygen used per hour and per gram of dried weight, then, was 4.10 decimilligrams for the first and $2.2 \mathrm{I}$ for the second. This is less than half the amount of oxygen used by oysters of comparable weight observed at the same temperature. To prop the shells open seemed hardly worth while, because the oxygen utilization under such circumstances would be abnormal on account of the resulting violent contractions of adductor muscles. It seemed best, therefore, to be content with the conclusion that under the circumstances of these experiments quahogs used only a small quantity of oxygen. 
Clamping these shells as in the experiments described for oysters showed that closed quahogs used no oxygen. Their very smooth shells apparently took almost no oxygen from the water. With various sizes of quahogs clamped and observed at $24^{\circ} \mathrm{C}$, results were obtained as follows: $0.37,0.25,0.38,0.23$, and 0.25 decimilligram of oxygen per hour. The empty shells, considerably broken in the process of opening, used a distinctly larger amount of oxygen than did the closed intact animal. The small amounts of oxygen taken up under these conditions are no more than would disappear from the sea water with a clamp in it.

It was clearly shown, however, that voluntarily closed quahogs did take up appreciable quantities of oxygen. In observations where the shells were apparently quite closed, various medium and large sized specimens took up, at $24^{\circ} \mathrm{C} ., 2.9,6.1,4.6$, and 4.3 decimilligrams of oxygen per hour. It would seem, then, that when voluntarily closed they do not remain shut absolutely tight, but take in small amounts of water through an aperture too narrow to be visible to the naked eye. The results are summarized in table vir.

\section{CONCLUSIONS.}

I. Oysters of medium sizes, at temperatures between $19^{\circ}$ and $28^{\circ} \mathrm{C}$., used from 7 to 35 decimilligrams of oxygen per hour per Ioo grams of entire weight. The amount varies with the temperature, so far as experiments show, according to simple relationship, so that the curve approximates a straight line. It is proportionally less for larger specimens. The oxygen utilization is, however, exceedingly variable, depending on a variety of conditions, most of which probably affect the openness of the shell.

2. Oysters when tightly closed take no oxygen from the surrounding water; at least, no more than is taken by empty shells.

3. Oysters show considerable resistance to lack of oxygen. Only exposure for more than a week to water containing very small quantities of oxygen proved fatal. This indicates that any conditions causing temporary decrease in the available oxygen are not a significant factor in oyster culture.

4. The common clam (Mya arenaria) shows a higher oxygen requirement than the oyster. This seems surprising, in view of the fact that clams so often exist in muds where oxygen-consuming putrefactions are going on. The oxygen requirements of clams and oysters in proportion to their dried weights are about equal.

5. Both clams and quahogs (Venus mercenaria) use no oxygen from the water when tightly closed, but the quahog takes up oxygen while slightly and invisibly open.

6. The oxygen requirements of the quahog are, under the conditions of these experiments, conspicuously low. 
